LENGUA Y LITERATURA CATALANAS 



\title{
«Josep és el nom més senyor que hi ha!»: onomàstica literària guimeraniana*
}

\author{
«Josep és el nom més senyor que hi ha!»: Guimerà’s Literary \\ Onomastic
}

MARIDÉS SOLER $(\dagger)$

(vorm. Universität Trier)

Recibido: Abril de 2016. Aceptado: Mayo de 2016

\begin{abstract}
Resum: L'onomàstica literària estudia la creació, tipologia i funció dels antropònims dins un context literari, els quals mitjançant diferents variants, desenvolupen una expressivitat determinada, que caracteritza un personatge alhora que també influeix en la trama argumental, és a dir, es tracta d'una especialitat interdisciplinària que investiga el significat literari dels noms dins una obra. El tresor dels antropònims guimeranians -alguns d'ells inventats, d'altres reals o presos de la història- ofereix una àmplia paleta sempre, però fent referència a l'espai i el temps en què transcorre l'acció i el paper que exerceixen, sia còmic, sia tràgic. Aquest article es concentrarà en la freqüència, la tipologia (noms parlants, sonors, classificadors i personificadors) i les diverses funcions que un nom pot desplegar dins el text d'acord amb els propòsits concebuts ja d'antuvi per l'autor.
\end{abstract}

Mots clau: Onomàstica literària - Onomàstica catalana - Guimerà, Àngel, Onomàstica - Teatre català s. XIX, Onomàstica - Teatre català s. XX, Onomàstica.

\begin{abstract}
The literary onomastic studies the creation, typology and function of the anthroponyms within a literary context; through different variants these names develop a typical expressiveness of the characters and also influence
\end{abstract}

* Aquest, malauradament, és un article pòstum. Maridés Soler ha participat en aquesta revista tant enviant articles com preparant avaluacions dels d'altres autors. És de plànyer que no hagi pogut fer-ne una darrera revisió. Hem pres la decisió de publicar-lo per tal com ja es podia considerar acabat del tot, tret de la correcció d'alguna errata detectada pels avaluadors -els informes dels quals, absolutament positius, només va conèixer parcialment-. Serveixi la publicació d'aquest estudi com a cordial i sincer homenatge a Maridés Soler, en agraïment per la seva generosa i constant col-laboració. 
the plot, in other words it is a interdisciplinary field, that investigates the literary meaning of the onomastic in a work. The treasure of Guimerà's names some of them invented, some others real or loaned from the history- offers a broad palette but always in relation with the space and the time by which the plot takes place and the role that they play, either comic or tragic. This article will deal with the frequency, typology (speaking, sonorous, classifiers, impersonators names) and the different functions, which a name can unfold within a text in accordance with the beforehand envisaged purpose of the author.

Keywords: Literary onomastic - Catalan onomastic - Guimerà, Àngel, Onomastic - Catalan theatre $19^{\text {th }}$ century, Onomastic - Catalan theatre $20^{\text {th }}$ century, Onomastic.

\section{ONOMÀSTICA LITERÀRIA}

El conjunt dels noms ficticis o reals d'una obra constitueix el paisatge literari onímic (Störig 1973: 44), el qual representa un element estructural important del text, sobretot del teatral, i contribueix alhora al seu reeiximent final, que dependrà en part que el nom d'un protagonista es correlacioni perfectament amb el seu paper i amb la trama argumental (Debus 2002: 82). Segons Carlson (1983: 289), un nom estampa una individualització en un grau màxim dins una estructura dramàtica. El fet d'anomenar un personatge marca l'inici de la personalitat d'un individu (Debus 2002: 13) i a través del nom els personatges teatrals adquireixen una identitat $\mathrm{i}$ individualització pròpia; per altra banda, també apareixeran personatges anònims, els quals seran designats només per llur ofici (Mossèn, municipal, ermità) i dels quals ja d'entrada s'esperarà que actuïn com a tals. Ja el Gènesi fa referència a la importància d'aquesta problemàtica en el moment que Déu atorga a Adam el poder d'anomenar els animals, la qual cosa li confereix automàticament potestat sobre ells i la possibilitat d'influir en llur caràcter, ja que nom i subjecte es troben normalment en una relació intrínseca. També Plaute (El persa, IV, 4, 73) fa al-lusió a la importància i influència del nom amb la famosa frase Nomen est omen. A diferència dels pares, els quals en batejar un nadó, li donen un nom «a priori», el qual, igual que una capsa de Pandora, pot o no influir en el caràcter de la criatura, un autor o autora, com un «Deus ex machina», anomenarà els seus personatges «a posteriori», és a dir crearà un nom literari ajustat a la personalitat i destí, que ja d'antuvi li ha assignat ${ }^{1} \mathrm{i}$ en conseqüència aquests es comportaran segons el pronòstic de llur nom.

L'onomàstica literària no es limita només a estudiar l'etimologia, morfologia, fonètica o semàntica aïllades, sinó també dins el seu entorn intertextual, és a dir, el context lingüístic i situacional (Störig 1973: 41), per la qual cosa la investigació s'estendrà també a les diferents variants d'un nom, a través de les quals desenvolupa una expressivitat determinada d'acord amb el seu significat

1 Debus (2002: 127-52) va realitzar una enquesta molt il-lustrativa entre autors alemanys moderns sobre llurs preferències, motius i exigències a l'hora d'anomenar un personatge. 
literari. En alguns casos existeix un marge de tolerància que permet una apreciació subjectiva essent possible d'altres interpretacions dins el context argumental. La importància d'un antropònim subsumeix totes les associacions, imaginacions i emocions neutres, positives i negatives, que resulta sobretot de la interrelació entre el nom i l'anomenat (Debus 2002: 33) inserits en una situació determinada.

\section{ONOMÀSTICA GUIMERANIANA}

Fàbregas (1971: 45-129) classifica la producció guimeraniana en quatre etapes que divergeixen completament entre sí quant a la temàtica i gènere alhora que denoten l'interès i la preocupació del dramaturg per adaptar-se a l'evolució dels corrents teatrals i respondre així a les expectacions del públic: la primera (1879-1890) versa sobre la tragèdia històrica o pseudohistòrica; la segona (1890-1900), que li va donar més fama, tracta de drames realistes rurals; la tercera (1901-1911) se centra en el realisme cosmopolita convencional, el naturalisme i el simbolisme, i la quarta (1917-1926) revela l'afany de l'autor d'intentar de nou retrobar la temàtica de la primera i segona etapa, que li havien donat molt èxit, alhora que incorpora temes de l'actualitat. La història de l'onomàstica assenyala que els noms estan subjectes a l'estètica i gust de cada època, per la qual cosa els antropònims guimeranians reflecteixen fidelment la història, geografia o la moda dels corrents literaris i alhora confereixen cert color local en denotar una època $i$ indret determinat $i$ caracteritzar un personatge. Els noms no són tan sols mers referents, sinó que transporten tot un bagatge cultural (Maguire 2007: 30, 49), esdevenint ambaixadors d'un moment historicogeogràfic. Així a la primera etapa dominaran noms històrics o pseudohistòrics medievals; a la segona, noms típics catalans; a la tercera, noms cosmopolites i sofisticats; i a la quarta correlaran la situació corresponent de la trama. La vasta producció guimeraniana reflecteix l'onomàstica catalana de tombants dels segles XIX i XX així com també inicia una renaixença de noms autòctons. ${ }^{2} \mathrm{Al}$ llarg de la seva extensa obra es pot detectar amb quina cura Guimerà, sempre molt sensible a detalls lingüístics, va triar l'onomàstica d'acord amb el medi social, històric i geogràfic on es desenvolupa la trama.

Guimerà exerceix al màxim la seva prerrogativa autorial, propugnada per Debus (2002: 55), que li permet de crear o trobar a plaer els noms dels seus personatges. Entre els antropònims, zoònims, teònims, noms de transports públics i de campanes es poden comptar al voltant d'uns 600 noms de personatges presents i absents. Els noms dels protagonistes van llistats alfabèticament a l'Apèndix des d'Abdalla a Ximena ${ }^{3}$ implicant sia noms rebuscats i sofisticats,

2 Miracle (1958: 440) afirma que Guimerà a través del seu teatre va fer que les noies catalanes ja no es diguessin Lolita, Pepita o Conxita, sinó Nuri o Maria Rosa. Tanmateix, cal observar que empra pocs antropònims genuïns catalans com Nuri, Monsa o Jordi amb només una sola referència de cada $u$.

3 A l'apèndix figuren només els antropònims esmentats al repartiment i no s'hi ha inclòs ni els protagonistes de Jesús de Nazaret ni els de La resurrecció de Llàtzer per no ser creacions típiques guimeranianes. 
sia vulgars i corrents ${ }^{4}$. En general predominen noms catalans típics, alguns d'ells originals i rebuscats: Oriola, Oliveta, Nadala ${ }^{5}$, Gueridó ${ }^{6}$ o catalanitzen alguns noms d'origen castellà, per exemple Rosària, de Rosario. Aquests antropònims poden investigar-se des de diferents perspectives (semiòtiques, psicològiques, lingüístiques, sociològiques, etc.), però aquest estudi es basarà en línies generals en la metodologia àmpliament reconeguda de Birus (1987) i Debus (2002), la qual es centra en la tipologia i funcions dels noms dins un context literari. D'entrada seran classificats segons el criteri formal de la frequiència amb què un nom apareix en el repartiment, la qual cosa permet una visió general del conjunt del panorama onomàstic alhora que d'antuvi denota ja les preferències del dramaturg envers certs noms ${ }^{7}$.

En el discurs necrològic per a E. Vilanova, Guimerà dóna algunes referències indirectes de la provinença d'alguns noms que trobarem en les seves obres: «Tothom em semblava que era amic meu perquè era la gent de l'Emili Vilanova. I em creia conèixer al senyor Salvador [...], a en Tit, el fusteret de falques [...], a cal Mingo de la Dagueria, a cal Nyerri del Pont de la Parra [...] i que no són ben simpàtics els municipals de l'Emili Vilanova, aquesta gent vinguda gairebé tota de fora de Catalunya, els Fernández, els Giménez i Menéndez ...» (Guimerà 1978: 1292-93).

\subsection{Freqüència}

\subsubsection{Antropònims}

\subsubsection{Masculins}

2 protagonistes (amb variants): Aymerich, Baltasar, Blai, Brandi, Carlot, Cebrià, Ciriac, Cosme, Gregori, Guerau, Hipòlit, Jaume, Joaquim, Marçal, Matias, Rafel, Robert, Roger, Salvador/Badori, Sebastià, Sergi, Severet/Severí, Ulric.

3 protagonistes (amb variants): Albert, Alexis, Carles, Demetri, Eloi, Enric, Domingo, Ferran/Nando, Francesc, Quic, Quirze.

${ }^{4}$ Donada l'extensió del tema, més apte per a una tesi doctoral i que sobrepassaria els límits d'un article, em concentraré només a tractar detalladament, com a exemple, alguns noms i llurs funcions.

${ }^{5}$ En una carta a Antoni Torrella, Guimerà li comunica: «El nom de Nadala és Nativitat. Jo no sé si en català es diu així, però em sembla que se'n podria dir» (Guimerà 1978: 1506).

6 Segons l'Oficina d'Onomàstica Catalana el nom de Gueridó en forma masculina seria una invenció guimeraniana. Tradicionalment Garidó/Garideta són els diminutius de Margaridó/Margarideta, és a dir un nom femení. Tanmateix a la rondalla popular En Garidet geperudet es troba també una variant masculina (Amades 1979: 457). Aquest diminutiu podria ser també una al·lusió críptica del nom de la seva mare Margarida Jorge.

7 En la majoria dels casos Guimerá evita de repetir un mateix nom. Per això, tant els antropònims masculins com els femenins que només són esmentats una vegada no hi són citats. 
4 protagonistes (amb variants): Bernat, Manel, Jordi.

5 protagonistes (amb variants): Miquel.

6 protagonistes (amb variants): Pere.

8 protagonistes (amb variants): Josep, Anton, Ramon.

9 protagonistes (amb variants): Tomàs.

16 protagonistes (amb variants): Joan.

\subsubsection{Femenins}

2 protagonistes (amb variants): Feliça, Felipa, Filomena, Laia, Niceta, Rita, Rosària, Tomasa.

3 protagonistes (amb variants): Isabel, Joana, Blanca, Francisca/Quica, Mònica, Oliveta, Munda.

5 protagonistes (amb variants): Agna/Mariagna, Maria, Pepa.

6 protagonistes (amb variants): Antònia.

10 protagonistes (amb variants): Rosa.

Aquesta classificació revela la preferència de Guimerà per «Joan» i «Tomàs» per als protagonistes masculins $i$ «Rosa» $i$ «Antònia» per als femenins. En aquesta llista cal afegir a més els noms de protagonistes absents, els quals només són al-ludits al text i que el públic accepta suplint en la seva imaginació l'actuació d'aquests ${ }^{8}$. La majoria denoten consorts o familiars, per exemple Blanca, esposa difunta del rei (FR: 212$)^{9}$ o Blanca, la mare del Saïd també morta (MC: 332), Hermetruda, esposa repudiada (JW: 153; 157), Rosa, dona del Quim (LB: 556), donya Paca, esposa de «l'habilitado» (LF: 820), Manela, la qual ha abandonat el Pep Botella per anar-se'n amb el Curro (PB: 1128), Peretó Barreja, propietari difunt de la botiga del Tano (LA: 301) o Sarus, pare difunt de Varogast (GP: 65-66). D'altres personatges absents seran Constancius, un general romà (GP: 77), els ibers Geric i Càrnia (IM: 1214), Remígia, una pobre que no falta mai a cap dinar de beneficència (DD: 665), Tigrot, que ha obert una taverna (DD: 667), l'Antonet sastre (LF: 837) o curanders, per exemple el vell Ramon, la presència del qual és evident quan el Roderic torna amb el cabrit curat mostrant així la intervenció benèfica d'aquell (MS: 929; 934), la Cuansolación (ST: 382) i la Meliona de La Batzuca (ST: 382) o el difunt metge Ismul (MC: 329), els dos nadons Joanet i Joanetet (SS: 191; EL: 255) i el Mossèn Golorons (LF: 837).

\footnotetext{
${ }^{8}$ Cal advertir que no figuren a l'Apèndix.

9 Totes les referències a les obres de Guimerà procedeixen de les Obres completes, 1-2; la llista de les abreviatures encapçala l'apèndix.
} 
Guimerà no anomena mai cap personatge amb el seu nom propi ${ }^{10}$ ni tampoc amb el dels seus familiars més propers (Agustí, Juli, Margarida). Contra el seu costum de catalanitzar els antropònims dels seus personatges, a la seva darrera etapa canvia aquesta norma i internacionalitza sovint l'onomàstica, bo i recorrent a noms sobretot d'origen francès, anglès o eslau (Meri, Mary, Gladys, Jon, Jeanne, Richard, Vladimir) o castellanitzats popularment (Cusefa, Juanito, Cosmito) per la qual cosa sembla que, per una banda, volia mostrar així la seva sensibilitat davant la realitat i, per l'altra, procurava adaptar-se als noms dominants de l'època.

$\mathrm{Al}$ repartiment no són mai esmentats els pseudònims, que alguns protagonistes utilitzen per encobrir la seva veritable personalitat, per exemple Brunegilda només coneix el rei Carles amb el nom d'Alduni (JW) i la sirena Rosa Vera (SE) es disfressa de patge adoptant el nom de Dardell per poder estar junt amb el seu amant convertit en palmera o en el cas del bufó Bernadot (FR), el qual tornarà a anomenar-se Didier en el moment en què es reconegut com a fill del rei; pel contrari, el vaquer Gueridó passarà a ser anomenat Arnolt en esdevenir rei (SE); a vegades, però, serà també a la inversa, ja que al repartiment figurarà només el sobrenom, per exemple Noi Sucre ${ }^{11}$ (LA), i no el nom veritable -Josep-, o afegirà al text un nom de pila, per exemple Poncio per al Méndez (LF). Alguns personatges tindran «noms múltiples» (Maguire 2007: 122), és a dir variants de un mateix nom, la qual cosa denota el grau de familiaritat o el nivell social dels personatges, per exemple la reina Blanca (RV) serà anomenada Blancaflor només pel Serní en record de llur amor juvenil; aquí Guimerà recorre sovint a interferències lingüístiques sobretot amb el castellà, per exemple Pepeta/Cusefa (ST).

Molts títols dels drames es basen sovint en antropònims (Gal-la Placídia, Judit de Welp, Andrònica, Jesús de Nazaret, Indíbil i Mandoni, Maria Rosa, Mossèn Janot, L'Eloi, Jesús que torna, Joan Dalla, La Baldirona, La resurrecció de Llàtzer, Titaina) o denoten un personatge a través del seu càrrec, origen o conducta (Rei i monjo, La reina jove, La reina vella, El fill del rei, La filla del mar, En Pòlvora, La pecadora).

\subsubsection{Zoònims}

Guimerà dóna nom a molts animals, els quals per motius obvis són absents $\mathrm{i}$ només són esmentats de passada, a excepció de la «Paloma», un gos (o gossa ${ }^{12}$,

10 Pel contrari, Shakespeare utilitza sovint el seu antropònim (William) i àdhuc en Al vostre gust anomena així dos personatges. En general, però, és usual que els autors bategin llurs personatges amb el seu nom propi. Per exemple, Goldoni (1923: 158) narra explícitament, en la seves memòries, que va anomenar «Carino», el pastor de Don Juan Tenorio, procedent del seu diminutiu «Carlino» suprimint la «l».

${ }^{11}$ És possible que Guimerà s'hagi inspirat per aquest sobrenom en la figura de Salvador Seguí (1886-1923), anomenat el «Noi del Sucre» perquè només menjava els sucres que li servien amb el café. El personatge guimeranià, però, té un tarannà completament diferent de l'històric, que era un anarcosindicalista assassinat al mig del carrer.

${ }^{12}$ El nom denota inequívocament una gossa, però en el text es fa referència només al genèric gos. 
el qual les acotacions preveuen que corri per l'escenari, i el «Moixaina», un cabrit ferit que el pastor primer duu al coll i després coixeja (MS: 929; 934). A diferencia d'altres països per als zoònims no recorrerà mai a noms de persona. Mitjançant el nom individualitza els animals, entre els quals no sols hi ha animals domèstics típics, sinó també bòvids, èquids, òvids i paquiderms.

gos: Frou-frou, Paloma, Galán.

gat: Mariquita, Negret.

bous/vaques: Lluerna, Morrinxo, Banya-riquer/Banya-viquer, Cama-lluent, Vaca Vedrana, Banyut, Maimona, Cornut, Ull de Perdiu (amb la preposició «de» parodia un títol nobiliari, que el Gueridó com a rei, acaba d'atorgar-li), Didassa.

cabra/cabrit: Moixaina/Moixaineta, Xurris, Marta (TB) ${ }^{13}$.

cavalls: Tordilla, Mal-de-Ventre, Fabrilo, Brillanta; eugueta: Iolanda; potret: Flendi.

elefant: Tgeli (amb el dígraf inicial tg- es vol denotar una suposada ortografia cartaginesa).

Aquests zoònims descriuen sovint alguna característica típica de l'animal, per exemple «Ull de perdiu», una varietat de la galena, podria denotar el color del pèl; «Flendi» -un joc que consisteix a llençar un objecte des d'una certa distància-, a la celeritat del potret; «Maimona», una vaca calmosa i «Froufrou», un nom sofisticat francès, apunta d'entrada a un gosset falder i no a cap gos de lluita. Igual que per als personatges Guimerà no estalvia a molts de sofrir un final tràgic, per exemple la Paloma s'escapa en direcció a les andanes del tren, el gat Negret el tiren daltabaix d'una finestra, l'eugueta Iolanda s'estimba, la vaca Didassa mor i el gos Galán el maten.

\subsubsection{Teònims}

En general abunden moltes invocacions a divinitats, sia cristianes, sia paganes, mitjançant les quals els protagonistes esperen ajuda o benevolència. Guimerà té cura d'adaptar perfectament cada divinitat a les creences dels protagonistes. Els cristians o jueus invocaran Jesús o Jehovà, per exemple quan l'Ismael ha perdut una moneda, es resignarà amb els mots: «Jehovà no ha volgut»; pel contrari, el Joan, que l'ha guanyada, comentarà: «Jesús, sí, mira-la» (MS: 969), i temeran Bujavà, Satanàs o Llucífer; els musulmans, per la seva banda, imploraran Al-là i Mahoma; els romans, Júpiter ${ }^{14}$, i, en una paròdia còmica, l'oncle Telm (FB) confondrà la «diossa Ceres», patrona de les collites,

13 Després de conèixer la Marta, el Manelic anomena una cabra amb el nom d'aquella: «tot lo dia la crida: Marta, ací! Marta, allà!... » (TB: 1391), la qual cosa podria interpretar-se que transfereix a l'animal proper, l'afecte que sent per la molinera llunyana.

14 A Indíbil $i$ Mandoni només s'anomenen déus romans; pel contrari, els ibers preguen a divinitats innominades, per exemple els «déus de la nostra llar»o «de la nostra terra». 
amb una divinitat cristiana. Noms ficticis per a divinitats es trobarà només en la figura burlesca del «Gegant dels Gegants dels Castellots de Bromes» (SE), el qual les bruixes i bruixots apel-laran a fi que els ajudi.

\subsubsection{Noms de transports públics}

Els vaixells ostenten en general noms que auguren bons auspicis, àdhuc presumptuosos (Maguire 2007: 31), basant-se en l'«omen est nomen». Guimerà esmenta en Jesús que torna (1917) el «Titànic», un vaixell real amb un nom infatuat, fent narrar l'enfonsament a la Gladys, una protagonista fictícia, que havia viscut personalment aquella tragèdia. Més modest serà el «Sant Cusé», un nom que presenta interferències lexicològiques i fonètiques castellanes, el qual va envestir unes roques i va enfonsar-se, la qual cosa va permetre el Jon de salvar el Bernabé (SS: 156; 164; 165). Un vaixell a rems és designat amb el nom grotesc de «Reial sabata» (SE: 1011-1012) adaptant-se al gènere còmic de l'obra (Soler, 2014: 105-121). A l'època guimeraniana s'utilitzaven les tartanes com a mitjà de transport i, d'acord amb els sentiments nacionalistes de l'època, és adient el nom de «La Catalana» i a fi d'accentuar el seu missatge el cotxer durà a més -segons les acotacions- una brusa i gorra amb aquest nom, denotant la pertenença a la companyia transportista, així com també a aquesta ètnia (LA: $301 ; 302)$.

\subsubsection{Noms de campanes}

$\mathrm{Al}$ món cristià és corrent que les campanes siguin batejades amb un nom, normalment femení. Dues peces nacionalistes guimeranianes fan referència a l'«Honorata» de la catedral de Barcelona, la qual cridava a Sometent per lluitar contra les tropes borbòniques: en Joan Dalla és esmentada de passada, però resta innominada, mentre que en Mestre Oleguer és incorporada a la trama argumental exercint un gran protagonisme simbòlic, ja que, per una banda, denota les lluites contra Felip V i, per l'altra, connota les aspiracions de llibertat del poble català ${ }^{15}$.

\subsection{Tipologia}

\subsubsection{Noms parlants}

Segons Debus (2002: 29) tots els noms consten d'una fisonomia pròpia, la qual pot suscitar ja d'antuvi simpatia o antipatia, sia per la seva semàntica, sia per possibles connotacions. Lessing va observar que per llur lexicologia i per llur etimologia alguns noms s'associen d'antuvi amb unes propietats determina-

15 En rendir-se Barcelona, Felip V va fer-la fondre, si bé poc després va ser construïda de nou. La campana actual data del 1865 i hi ha tingut tres predecessores dels anys 1393, 1760 i 1762; toca els quarts i, l'Eulàlia, les hores. 
des (Hamburgische Dramaturgie, XXIV, 9, 283, citat a Birus 1987: 40). Mitjançant la transparència semàntica, els escriptors poden definir, ja d'antuvi, certes característiques de llurs personatges ${ }^{16}$ (Debus 2002: 58-64). Per exemple el gat Negret, ja d'entrada, denotarà el color del seu pèl o noms associats amb animals transferiran les propietats d'aquests als personatges, per exemple Cabirol, Esquirol o Tigrot; Jan Talèia, un personatge de baixa condició, indica una persona amb una forta dèria, en aquest cas antimonàrquica; Ripollès suggerirà una procedència geogràfica; Somiquet, tant pel diminutiu com per la semàntica, descriu un jovenet, que ploriqueja sovint; o el senyor Llargas, un entremetedor astut de les eleccions municipals ${ }^{17}$. Els noms de les bruixes i bruixots de La santa espina parlen també per ells mateixos: Apagallums, Babarotes, Pegadolça, Tallanassos, Secallona, Teranyina o Pa-i-ceba.

Carlson (1983: 293) remarca que molts noms parlants assenyalen sovint una professió o un ofici, sent sobretot molt corrents els motius connotats, els quals abunden en els drames rurals. Per exemple el pagès Xeixa (un tipus de blat) (TB) o el pescador Mòllera (FM), el sobrenom del Pòlvora farà referència al caràcter explosiu del personatge $\mathrm{i}$ a les seves activitats revolucionàries. D'altres denotaran la posició dins la família, per exemple Xic o Gran, o indicaran un defecte físic: Gepa (MR), la qual cosa podria ofendre l'al-ludit, si bé en aquest cas és el contrari, ja que, com el mateix protagonista explica, li agrada perquè li recorda la tara física del seu fill ja mort, que era geperut; o indicaran un delit, per exemple Gana (LA), que caracteritza un nen que sempre vol menjar, o el Pep Botella $(\mathrm{PB})$, un home que beu. Als drames ciutadans recorrerà a motius connotats amb un cert deix despectiu i còmic, ja que els motius de Tripereta o Cotillaire (també «Corsetero» per semblar més elegant), no són gaire adients per a candidats municipals. El primer fa referència a un ofici, que ja no exerceix, i el segon, procura enaltir-lo amb el comentari: «Noia, no cotillaire, sents? Fabricant de cotilles a l'engròs. [...] I proveïdor de la Reial Casa, per servir-los» (LF: 806).

Molts protagonistes seran anonimitzats a travès de llur ofici o càrrec restant al llarg de tota l'obra innonimats. Amb l'anonimat s'accentua la diferència entre personatges amb nom i sense, la qual cosa destaca la importància de posseïr-ne un (Debus, 2002: 89). Aquest fet és corrent quan es tracta de personatges figurants (soldats, pagesos, pescadors), però també n'hi ha d'altres, els quals, encara que tenen un paper secundari, només són anomenats per llur ofici, per exemple Mossèn (TB) o Hostalera ${ }^{18}$ (TI); a Les monges de sant Aimant, Pere l'ermità predicarà la creuada a Terra Santa, però en el text només serà anomenat pel seu

16 A The importance of Being Earnest (La importància de ser Frank) (1895), Oscar Wilde juga clarament amb la polisèmia del nom anglès del protagonista Ernest/Earnest (Ernest/seriós), la qual cosa es reflecteix en la traducció catalana del nom a fi de mantenir fidelment el joc de paraules.

${ }_{17}$ També es podria relacionar amb la frase feta «saber-la llarga», és a dir, tenir molta experiència, però pocs escrúpols.

${ }_{18}$ En el duet entre l'Hostalera i l'Eudald es personifica una desigualtat onomàstica, ja que mentre l'una és definida només pel seu ofici, l'altre és identificat a través del seu nom propi, que el caracteritza com a individu. 
càrrec (L'Ermità) i, en el repartiment de la versió operística, Euda d'Uriach, ja no s'esmenta el seu antropònim.

Guimerà denega el nom als protagonistes de dues narracions: El nen jueu i El gos de casa. En la primera ja al títol denota clarament la pertinença ètnicoreligiosa del personatge principal, el qual continuarà sent anomenat així al llarg de tot el text, encara que vagi ser batejat -no es revela el nom-, denotant així el rebuig del poble d'acceptar-lo com un dels seus. En la segona tampoc no li atorga cap zoònim en el títol i només adesiara al text l'anomenarà Galán, mentre que el narrador restarà anònim. En el cas dels músics d'En Pòlvora, té lloc una escena còmica basada en el costum d'anomenar-los per llur instrument, la qual cosa aixecarà protestes del Flauta, que cada vegada els corregeix insistint en ser interpel-lat pel seu cognom: Lladons! (PO: 1278).

Els diminutius denoten d'antuvi una relació afectiva especial, sia dirigint-se a una criatura o a una persona coneguda, però també poden indicar nivells de diferents classes socials en tractar persones de condició baixa, per exemple subalterns i en certes ocasions àdhuc poden tenir un ressó despectiu. Els sufixos catalans més corrents per expressar afecció o desdeny són:

-et / -eta: Guimerà recorre sovint a diminutius per als personatges femenins secundaris: Esperanceta, Antonieta, Carmeta, Lluïseta, Agneta, Blanqueta i també pels masculins: Rufet, Baltasanet, Joanet. A fi d'augmentar el sentiment d'afectivitat, empra un «diminutiu doble» per a un nadó: el Miques anomenarà el Joanet, «Joanetet» argumentant que és més fi (EL: 289; 292). A la fase cosmopolita, on es produeixen més interferències lingüístiques, sobretot castellanes, alguns personatges ostentaran diminutius castellans, especialment per denotar alhora una classe social elevada, si bé connotant un cert deix ridícul ${ }^{19}$ : -ito / -ita: Juanito, Cosmito, Salvadorita. Un sufix diminutiu no gaire corrent és -ic: Manelic ${ }^{20}$, el qual, a més de conferir una cadència molt melòdica, individualitza ja d'antuvi el pastor de Terra baixa, el qual tractarem amb detall més endavant.

D’altres sufixos típics catalans són: -ó / -ona: Marcó, Miqueló, Josepó, Peretó; Rosó, Baldirona, Candiona, Teresona, Gasparona.

-às és el sufix augmentatiu i pejoratiu més usual; sovint denota la condició baixa del protagonista, però també amistat, per exemple Miquelàs; el sufix -ot tenia antigament també un sentit diminutiu afectiu ${ }^{21}$, però al teatre guimeranià normalment fa referència a personatges de classe social humil: Bernadot, un bufó; Miquelot, un pagès; Tomasot, un vailet de masia; Joanot, un pirata renegat; o Perot, un almogàver.

19 Malgrat el seu interès evident per a l'onomàstica catalana, Guimerà apel-lava afectuosament les filles del Pere Aldavert, amb qui va conviure gairebé tota la seva vida, amb els diminutius castellans: -ucho i -ó: Sarucho/Sarachucho (Sara) i Adrianó (Adriana), la qual cosa venia influïda possiblement per l'idiolecte de la seva mare canària (Guimerá 1978: 1480-81).

${ }^{20}$ A la seva novel-la curta Rinconete y Cortadillo Cervantes també utilitza diminutius insòlits per als seus protagonistes: Rinconete, de Rincón i Cortadillo, de Cortado.

${ }^{21}$ L'escriptor i noble valencià Joanot de Martorell (1410-1465) n'és un bon exemple. 
Els hipocorístics es formen normalment mitjançant l'afèresi denotant una intenció afectiva: Cisa (Narcisa), Deri (Desideri), Faci (Bonifaci), Rufet (Ruf/ Rufí), Gori (Gregori) o Taneta (Gaietana). Sovint s'entrellaçaran amb interferències lingüístiques castellanes, per exemple: Tano (Gaietà), Nando (Fernando), Mingo/Minguet (Domingo), Sèbio (Eusebio) o Candro (Alejandro).

En alguns noms sembla que podria detectar-se una metàtesi, per exemple Llèdia (GP) procedent de Lleida o Titaina de Titània ${ }^{22}$.

\subsubsection{Noms simbòlics sonors}

A més dels noms, els quals ja tenen una sonoritat pròpia per ells mateixos, un autor o autora pot accentuar-la mitjançant determinats fonemes o lletres i també amb l'al-literació, assonància, elements mètrics, formes arcaiques o arcaïtzants, abreviacions, augmentatius jocosos o expressius i transformacions fonètiques i morfològiques. La fonètica d'un nom irradia una fascinació especial, la qual ve donada per la presència de vocals clares, sobretot la «a», mentre que la «u» amb el seu so fosc connota més aviat associacions fúnebres ${ }^{23}$ (Debus 2002: 67-68; 85). A les obres guimeranianes moltes protagonistes femenines principals ostentaran antropònims amb «a»: Marta, Aggata, Nadala, Blanca o Agna; i també alguns personatges masculins, per exemple Marçal. Sovint es combinarà també amb les vocals clares «e» i «i »: Laia, Àlbia, Cecília, Amèlia, Niva, Egla, Elda o Elena; Saïd, Sebastià, Serní, Severí, Nataniel, Ferran, Valentí, Vèlia o Carles. Guimerà utilitza poc noms amb «u», llevat d'alguns noms d'origen germànic: Urla, Urilda i Brunegilda o el nom típic català: Tura i el motiu connotat: Trumfos. La «u» dels diftongs «eu» ve assuaujada per la «e», la qual cosa suavitza la pronúncia, un bon exemple dels quals són els noms de dos protagonistes principals: Euda i Eudald.

Existeixen molts estudis sobre la postura dels escriptors davant l'onomàstica, els quals s'hi veuen confrontats ja d'antuvi amb el fet de batejar llurs personatges. Goethe opinava en Poesia i veritat que també al món real, en anomenar algú, caldria que s'orientessin sobretot en la sonoritat del nom, especialment per a les nenes (citat per Debus: 2002: 67). Cal remarcar, però, que la sonoritat dels noms es basa en part també en un apreciació subjectiva influïda sovint per la semàntica. Guimerà era molt conscient de la sonoritat dels noms i demostra un interès especial envers l'onomàstica, intercalant sovint comentaris positius o negatius, sia del mateix interessat, sia d'altres personatges, sobre el significat, la connotació, recepció, acceptació o rebuig d'aquests. Per exemple sobre el seu nom el Miques explicarà: «Miques; que vol dir Miquel» (LE: 258). En aquest

22 Titaina podria interpretar-se com una metàtesi del nom de la reina Titània de Somni d'una nit d'estiu de Shakespeare, que el dramaturg català admirava molt i va influir en algunes de les seves obres (Soler 2012).

${ }^{23}$ Noms amb la consonant fosca «r» desvetllen connotacions negatives, per la qual cosa Debus (2002: 67-68) va detectar que a les novel-les de Heinrich Böll no hi figura mai cap antropònim femení amb aquesta consonant i que Jean-Paul, per la seva part, empra noms monosil-làbics per a personatges anodins i en els bi- i trisil-làbics predominen els sufixos diminutius -lein, -le i -el. 
cas el canvi inusual del fonema «l» per la «S» final contribueix alhora a un canvi semàntic, el qual ara connota un personatge insignificant per comptes d'un arcàngel. Sobre el nom de Dèvora un personatge dirà al seu marit: «El primer que has de fer és canviar-li el nom» (MI: 199); pel contrari, quan el rei Hildebrand s'assabenta del nom de l'Elda, exultarà sobre la bellesa d'aquest: «Què bé sona aquest nom»(DD: 683); la Nuri comentarà: «Se diu Manelic. Quin nom més bufó! Fa cabrit, oi?» (TB: 1390); i la Gasparona elogiarà: «Com que Josep és el nom més senyor que hi ha!» (LA: 301).

L'addició d'un complement omínic a un antropònim corrent i vulgar pot conferir una identificació especial al portador o portadora d'aquest, ennoblint alhora el nom bàsic, la qual cosa Guimerà utilitza sovint, per exemple: Pere Màrtir, Jan-Toni, Pia Munda, Rosa Vera.

A través de la semàntica un nom ofereix associacions simbòliques, a la qual cosa molts escriptors recorren sovint a l'hora d'anomenar un personatge, per exemple les dues protagonistes dites «Isabel» seran dones fatals, la qual cosa podria apuntar a la Jezabel bíblica, no tan sols etimològicament sinó també per la connotació, mentre l'única que duu l'hipocorístic Bel és una criada innocua. Sovint s'associa també amb un objecte, normalment agradable ${ }^{24}$, per exemple $\operatorname{Rosa}^{25}$, una flor dilecta dels modernistes, s'associa amb un perfum agradable i una forma i colors bonics i, com hem vist abans, és el nom femení més freqüent en el teatre guimeranià; també «Blanca» és un epònim, el qual connota puresa i innocència i potser recordava al dramaturg l'hàbit blanc de novícia de l'Emília Palau, amb qui la mare d'ell hauria volgut que es casés, i la qual Guimerà visitava sovint (Miracle 1958: 329).

\subsubsection{Noms classificadors}

Als drames i novel-les naturalistes els autors recorren sovint a noms classificadors, els quals són expressius, però no etimològics (Birus 1987: 47); d'antuvi tenen la finalitat de definir els protagonistes segons criteris religiosos, nacionals, socials o senzillament literaris. També poden denotar aspectes geogràfics, regionals o locals, si bé caldrà tenir en compte el context de l'època corresponent (Debus 2002: 32, 64) i segons Maguire (2007: 42), alguns noms estan predestinats ja d'antuvi a caracteritzar papers determinats, sia còmics, sia tràgics. Ja d'entrada noms exòtics i sonors definiran una persona de posició elevada, noms corrents i vulgars, una posició social baixa; l'addició del parentesc conferirà familiaritat, per exemple l'Oncle Telm.

${ }^{24}$ Un bon exemple de la influència dels noms és l'anècdota que narra com ambaixadors francesos van ser enviats a Castella per escollir una princesa per a esposa del rei Luís VIII. Podien triar entre la princessa Urraca, molt bella, i Blanca, més aviat lletja. La decisió va ser a favor de la Blanca perquè els ambaixadors no volien presentar-se a París amb una futura reina dient-se Urraca (Carlson 1983: 30).

${ }^{25}$ A El pati blau de S. Rusiñol (1973: 1190), el Jacint diu a l'Agna-Rosa: «Jo crec en la simpatia dels noms de les coses [...] i veient-la, ja hi havia de veure en vostè una rosa del perfumat mes de les roses!». 
Ja Aristòtil recomanava que a les tragèdies històriques es mantinguessin els noms dels personatges verídics (Poètica, 1451b, 5-10), la qual cosa Guimerà practica tant a les bíbliques com a les històriques recorrent a noms històrics $o$ pseudohistòrics ${ }^{26}$, els quals procura adaptar a la fonètica i grafia de l'època: jueus: Jesús, Llàtzer, Caifàs, ibers: Indíbil, Mandoni, Baàlia, Saut o romans: Mànlius, Ròmul. Per als antropònims i patronímics medievals poua d'una àmplia paleta de fonts històricoliteràries d'aquella època: germànics: Arnolt, Roderic. Hildebrand, Gualter, Brunsberdec, Brunegilda, Urilda; occitans, amb el sufix -ac: Armanyac, Desirac; catalans, amb els sufixos -ll i -ny: Xeminells, Restany. Als drames orientals i àrabs l'onomàstica contribuirà també al color local denotant ja d'antuvi la pertinença del protagonista a una ètnia determinada: Andrònica, Ofíria, Hirak, Bacahit, Heraclias o Abdalla, Hassèn, Selim, Sema, Saïd, Malek. Com hem vist abans, als drames del segle XX, apareixen sovint noms internacionals i a Jesús que torna, un drama escrit en plena I Guerra Mundial, la trama del qual té lloc en una cort imaginària centroeuropea en guerra, recorre a una onomàstica, la qual connota personatges d'aquells països: Comte d'Orlof, Rei Rodolf, Príncep Demetri, Madame Gringoire, Baró d'Arding. En general, però, per als noms nobiliaris de corts fictícies mostrarà una preferència per a noms marcadament catalans: Marquesa de Seguret, Argonat, Arlet, Aymerich, Rosamaia.

En les obres urbanes del s. XX els protagonistes ostentaran sovint noms i cognoms castellans, la qual cosa reflecteix el fet d'una societat bilingüe: Remedios, Baldomero, Domingo, Hierbas i, sobretot per als patronímics dels municipals, Méndez i Menéndez. Sovint es produeixen interferències fonètiques i morfològiques tant en els noms de pila com en els patronímics. Aquestes interferències exerceixen diverses funcions literàries, sia per ridiculitzar un estament, que recorre al préstec de sufixos castellans per a diminutius amb la finalitat de mostrar que pertany a una classe social més elevada, per exemple Juanito, Cosmito, sia per manifestar la ignorància d'una protagonista mitjançant una fonètica errònia alhora que, pel contrari, creu que sona més elegant, per exemple, quan a l'inici del drama el Miquelàs crida la Pepeta, aquesta no l'entén fins que li diu Cusefa: «-Aquí sempre t'hem dit Pepeta. / Cusefa: - [...] Doncs a Barcelona Cusefa» (ST: 343-44) o la curandera Cuansolación, el nom de la qual el Candro tindrà dificultats de pronunciar: «És que donya Cuan... Cuansolación...» (ST: 382). Sobretot a La farsa, on ridiculitza les eleccions municipals, es produirà el xoc més evident entre els noms i el tractament de cortesia catalana i castellana, per exemple gairebé tots els personatges seran interpel-lats amb «Don» $\mathrm{i}$ «Donya», per exemple el senyor Fruitós passarà a ser «Don Fructuoso» o un municipal caurà en la redundància: «El senyor don Cosme» (LF: 834) i a La sala d'espera, el senyor Sala no es cansarà de protestar en ser interpel-lat com a «senyor Sebastià» i no «don Sebastià»: -«Don, don: no costa pas tant! Si és més curt!» (SP: 777).

${ }^{26}$ L'onomàstica dels drames històrics, reals o ficticis, integra una constel-lació de noms relacionats entre ells; Shakespeare, Schiller o Racine s'inspiraven generalment en cròniques històriques per als noms de personatges secundaris o almenys en creaven uns que sonessin com a tals (Carlson 1983: 286-88). 


\subsubsection{Noms personificants}

Jesús que torna és un bon exemple dels denominats noms personificants, els quals transfereixen les característiques típiques d'una persona històrica completament aliena a l'obra a un personatge ficcional, bo i suggerint alhora una actuació semblant a la del personatge real (Debus 2002: 70-71). Així, tot i que el protagonista s'anomenarà Nataniel mitjançant el títol de la peça se l'associa ja d'antuvi amb el paper del Messies junt amb una missió de pau i un do profètic, que vol exercir, fins a sofrir la consegüent mort final.

\subsection{Funció}

En una obra literària els noms exerceixen també una funció de caracterització, la qual permet de classificar ja d'antuvi el paper d'un protagonista (Debus 2002: 89) donant-li alhora una forma concreta i una identitat pròpia ${ }^{27}$ (Debus 2002: 75) i, en alguns casos, per exemple a Lohengrin, la revelació del nom del protagonista contribuirà a l'anagnòrisi de la trama, ja que, en donar-se a conèixer, caldrà que abandoni l'Elsa de Brabant.

Prenent com a base la freqüència dels noms, passarem a estudiar ara amb més detall alguns exemples de llur funció dins l'obra guimeraniana. Els noms masculins més repetits són «Joan» $i$ «Tomàs» $i$ els femenins «Rosa» $i$ «Antònia». Com ja hem vist abans, Guimerà se sentia inspirat per l'onomàstica d'algunes figures d'E. Vilanova per la qual cosa és interessant de citar aquí un comentari d'aquest sobre el nom de Joan: «Tinc, ja de molt enllà formada l'idea de que la major part dels que es diuen Joan han de ser una classe de subjectes senzills, catxassuts i placenters [...] i una disposició bondadosa per a suportar pacientment aqueixa multitud de defectes que cada u observa en lo pròxim [...]» (Vilanova 1949: 238) ${ }^{28}$.

Guimerà sembla alinear-se també amb aquesta opinió, batejant divuit personatges amb «Joan» i a més l'emprarà com a títol de dues obres: Mossèn Janot i Joan Dalla. Per altra banda, era conscient de l'ús frequient d'aquest nom en les seves obres, ja que a Jesús que torna un personatge el recalcarà amb la reiteració: «En Joan el jardiner, i el seu germà, i una filla d'en Joan, i sa cunyada, que també es diu Joana...» (JT: 455). Sobretot abunden les variants diminutives, per exemple Joanet, Joanetet, Joanot, Juanito; hipocorístiques: Jon; i compostos amb un altre nom: Joan Taleia i Jan Toni. Donada l'aparició repetida d'aquests noms és obvi que no es limiten a denotar una sola posició social, sinó que es troben estesos a través de tots els estaments de la població ${ }^{29}$. Així designaran

27 A Josep i els seus germans, Th. Mann fa dir a Putifar que el nom és la forma més curta per definir una persona (citat a Debus 2002: 75).

28 Aquesta observació literària ve corroborada amb la frase feta de la saviesa popular: «Ésser un bon jan», referint-se a una persona de bon tarannà.

${ }^{29}$ Cal recordar que ha estat també el nom de dos reis catalans: Joan I, l'Amador de la Gentilesa (1350-1396), i Joan II (1398-1479). 
almogàvers nobles ficticis (Joan de Nargó) ${ }^{30}$, un violinista (Joan Lladons), un pirata renegat (Joanot) ${ }^{31}$, un mariner (Jon), un jove de l'alta societat (Juanito), un patriota (Joan Dalla), capellans (Pare Joan, Mossèn Janot), un revolucionari (Joan Taleia), un contrabandista (Jan-Toni), el nét d'un moliner (Joanet) i nadons (Joanet, Joanetet), un teixidor, un jardiner i gent del poble. La predilecció afectiva del dramaturg per aquest nom ve corroborada pel fet que dels dos nadons, que apareixen en la seva obra, tots dos duen aquest nom en diminutiu i, com hem vist abans, àdhuc l'un amb diminutiu doble: «Joanetet». Set dels divuit «Joan», sia amb variants nominals, sia amb additius, incorporaran papers principals: Joan Dalla, Mossèn Janot, Joanot, Jan-Toni, Jon, Juanito i només un respondrà senzillament al nom de Joan (EL); la resta es repartirà entre personatges més o menys secundaris. L'edat dels protagonistes anirà des de vells fins a nadons. Amb excepció del Jon (SS), que comet un assassinat, els altres protagonistes confirmaran el suposat caràcter bondadós atorgat al nom i tres d'ells moriran víctimes d'actes violents: Joan de Nargó i Joan Dalla en lluites i Mossèn Janot, assassinat.

Com a contrapartida femenina, les quatre protagonistes, que duen el nom de Joana, amb una excepció, no representaran mai cap paper important; totes són joves i pertanyen a la classe social baixa: l'hipocorístic Jana, una amiga de la Niceta, Jeanne, una minyona amb un antropònim francès i Joana, la cunyada d'un jardiner. La protagonista principal de La boja, una minaire, s'anomenarà Joana, la qual, però, no titula la peça, sinó només ve denotada amb el motiu connotat amb què se la coneix despectivament, tot que que no correspon a la realitat.

Tomàs és el segon nom masculí més freqüent, amb nou protagonistes, els quals pertanyen a la classe social baixa i representaran només papers secundaris: gent del poble, un criat, un moliner, un obrer d'una fàbrica, un ferroviari, un pagès i un vailet d'una masia, el qual serà l'únic que serà anomenat per el diminutiu Tomasot. Només dues dones duran el nom de Tomasa i, igual que els seus homònims masculins, també tindran una posició baixa i papers secundaris representant dones del poble, sent una d'elles anomenada amb el diminutiu Tomaseta.

El nom femení més repetit és el de Rosa, que compta amb deu protagonistes amb variants, sia diminutius (Rosella, Roseta, Rosó), sia amb compostos (Rosa Vera, Rosamaia, Maria Rosa ${ }^{32}$ ). Aquest nom figurarà també en dos títols: Maria Rosa i Rosa de Lima, representant ambdues protagonistes papers principals igual que la Rosó de Mossèn Janot, una sirena/patge (Rosa Vera) i una viuda d'un caminaire (Maria Rosa) mentre que la resta actuarà en papers secundaris en diferents nivells socials: una dama de la cort (Rosamaia), una artista/monja

${ }^{30}$ Per a aquest nom Guimerà va inspirar-se potser en el Coll de Nargó de la Serra de Sant Joan (Alt Urgell).

31 A la tragèdia el Joanot es penedirà i al final ajudarà els cristians al contrari del musical homònim de Dagoll Dagom, on continuarà fins el final sent un personatge traïdor i murri.

32 Caracava (1933: 64) suposa que el nom de Maria Rosa era un record del seu amor juvenil (Maria) i de la filla d'aquesta (Rosa). 
(Rosa de Lima), una minyona (Rosa), parentes (Rosa, Roseta), una noia de poble (Rosella) i una pagesa (Maria Rosa). L'edat variarà entre noies joves i adultes. Totes exerciran papers benèvols i només una (Rosa de Lima) sofrirà un final tràgic sent morta durant una revolució.

Antònia és el segon nom femení més freqüent; sis protagonistes el duen amb la variant Antonieta, la majoria de les quals, amb excepció d'una cosina de la Pia Munda, viuda d'una certa posició elevada, són dones de condició social baixa: una minyona, una pagesa i una senyora de companyia i la dona del Ramon de La pecadora. Totes representaran papers secundaris, menys aquesta darrera, la qual serà l'antagonista de la Daniela. Ja d'antuvi el contrast entre ambdós noms denotarà la diferència de nivell social entre ambdues dones: per una banda, la Daniela, una cantant de París, amb un nom sofisticat i elegant i, per l'altra, l'Antònia, un nom corrent i vulgar, que lluita reeixint-hi per conservar l'amor del seu marit. L'edat de totes elles girarà entre joves fins mitjana edat i cap d'elles no actuarà en un paper de persona malèvola, amb excepció de l'Antònia de Terra baixa, una pagesa xafardera, que es burla de la Marta.

Antoni és la contrapartida masculina i, amb vuit personatges, el tercer nom más freqüent ${ }^{33} \mathrm{amb}$ les variants: Anton, Toni i Tonet. Fora del Toni, el bover enamorat de la Rosó de Mossèn Janot, tots tindran papers secundaris poc rellevants: un veí, un moliner/obrer d'una fàbrica, un ferroviari, pagesos, un veí ocellaire, un obrer o un contrabandista (Jan-Toni). A vegades aquests personatges secundaris seran companys d'un altre personatge també secundari anomenat Tomàs (SP; TI), la qual cosa sembla denotar la preferència de l'autor envers ambdós noms, adients al seu parer per a persones de classe social baixa. L'edat anirà des de joves fins a vells i tots, llevat el Jan-Toni, exerciran oficis respectables i llur actuació serà la de persones bondadoses.

Per al públic que desconeix el nom dels personatges, Guimerà l'intercala en molts diàlegs com a mitjà d'identificació alhora que revela la seva recepció per l'interlocutor, ja que a través d'aquest li permet de «conèixer/reconèixer» una persona. Per exemple quan el Miquelàs diu: «-Què hi ha, Niceta?», el Tit que ho escolta, comentarà: «-Niceta. Et dius Niceta.», a la qual cosa la Niceta respondrà lacònicament: «Ara!» (ST: 354) o el Jaume de La festa del blat repeteix amb encís: «Se diu... Oriola. Ja m'en recordaré, ja; Oriola, Oriola» (FB: 1345) o, quan l'Eudald sent que el cor de pagesos s'acomiada amb «Adéu, Titaina, adéu!», exultarà: «-Es diu Titaina!...» (TI: 1101). Un cas molt clar d'identificació el trobem en el Serní, un personatge cec de La reina vella. Quan aquesta torna al poble, on havia passat la seva infantesa, el Serní no la reconeixerà fins que no sap el seu nom, el qual serà la clau que li obrirà el record de llur passat comú passant tot seguit a anomenar-la familiarment «Blanqueta», com abans, la qual cosa connota alhora certa relació sentimental íntima entre ambdós (RV: 1066-67; 1075-76). Una altra «Blanqueta» és la protagonista de L'ànima és meva, la qual ja en el repartiment ve anomenada

${ }_{33}$ Si s'hi compta el compost Jan-Toni, el nom d'Antoni iguala en freqüencia amb el de Tomàs. 
només amb el diminutiu, denotant així ja d'antuvi una relació afectuosa amb tots els altres personatges (mare, padrastre, enamorat, tia); a Mar i cel, Guimerà confereix al nom de Blanca, el qual per la seva semàntica ja emet efluvis de bonda ${ }^{34}$, una certa mitificació en associar el nom de la protagonista principal amb el de la mare cristiana morta del Saïd, la qual cosa provoca records dolorosos en el pirata alhora que l'impel-leix emotivament envers la cristiana captiva; també a El fill de rei, la reina difunta, mare de Bernadot, s'anomenava Blanca.

Manelic és un antropònim de la literatura catalana, el qual denota d'antuvi una identificació inequívoca del pastor de Terra baixa, el qual per la seva peculiaritat morfològica contribueix al dramatisme de la ficció caracteritzant-lo com una figura immortal de la literatura catalana. Guimerà empra aquest diminutiu, sia per cridar l'atenció, sia per accentuar la seva posició innegable de protagonista principal. Per una banda, li atorga cert deix afectiu, però per l'altra, amb motiu del seu ús relativament insòlit, li atorga un grau màxim d'individualització, bo i apartant-lo de la connotació enxiquidora, tot ornant-lo alhora amb atributs de valentia i honradesa. Encara que s'associa amb un nivell social baix a través del seu comportament segur d'ell mateix i sense compromisos, ha esdevingut una figura universal. Com veurem més avall, es tracta d'un nom de traducció difícil, ja que conté una polisèmia amb moltes connotacions antagòniques dins el context de pastor-heroi (diminutiu, condició baixa, caràcter noble, valent). Si Guimerà hagués recorregut al diminutiu usual de «Manelet» hauria minimitzat automàticament -àdhuc amb un cert matís còmic- la imatge del pastor, ja que no hauria estat apropiat per caracteritzar un home que, si bé ingenu, mata llops amb les meres mans i, al final, també l'amo Sebastià, quan lluita amb ell. Guimerà batejarà amb «Manel» tres altres protagonistes, tots ells amb papers secundaris anodins; aquests antropònims es basaran en diferents variants d'acord amb la posició representada pel protagonista: Manel, un minaire (BJ), Manuel, un diputat (AC) i Manelet, el fill del manyà Deri (FA).

\subsection{Traducció}

Els noms són signes bilaterals amb una forma i contingut propi (Störig 1973: 24), els quals a través de llur significat etimològic desvetllen associacions emotives inherents a una cultura determinada per la qual cosa les traduccions caldria que s'adaptessin als coneixements dels receptors (Nord 1991: 99) o fossin ornades amb reminiscències exòtiques per tal de suggerir el color local adient a la trama argumental. Caldria que la traducció de l'onomàstica teatral tingués en compte les possibles denotacions i connotacions que pot despertar en l'espectador i el paper que exerceixen dins la peça, les quals, potser per a un

${ }^{34}$ D'antuvi els noms ficticis es poden tergiversar a fi que denotin un significat d'acord amb el caràcter del protagonista, la qual cosa en la realitat és completamente fortuïta. Per exemple Blanca de Castella (1188-1252), reina de França i mare de sant Lluís IX, va exterminar cruelment i implacable els càtars. 
públic de diferent àrea cultural, serà difícil d'interpretar ${ }^{35}$. D'aquí que caldria que el traductor retransmetés adequadament les unitats textuals relevants de l'estructura i llurs funcions comunicatives, per exemple el nom de «Manelic» no provocarà cap connotació coneguda per a un públic no català.

Per a l'obra guimeraniana es recorre a diverses possibilitats a l'hora de traduir un nom al castellà: a) nom igual o castellanitzat amb canvis gràficomorfològics: Rosa, Gregorio, Carlos, Sebastián; b) transposició fonètica: Guillén per Guillem, Chepa per Gepa; c) transposició literal: Padre Juanico per Mossèn Janot, i d) substitució: Ramón per Marçal, Pedro per Manelic, Morrucho per Xeixa. A continuació passarem a estudiar amb detall algunes de les obres principals traduïdes al castellà ${ }^{36} \mathrm{i}$ també les versions musicals franceses, alemanyes $\mathrm{i}$ italianes.

Mar i cel fou traduït per Enrique Gaspar i estrenat en castellà a Barcelona el 26.VII.1888 (Martori 1995: 13-14), la qual cosa potser va influir en el fet que el nom de Ferran no fos traduït pel seu equivalent castellà, llevat de l'accent, igual que Osman. D'altres noms han estat senzillament traduïts, per exemple Carles i Roc (Carlos, Roque); Joanot és anomenat Juan, amb la qual cosa es perd l'afectivitat i en certa manera la connotació pejorativa d'aquest personatge i, per a Guillem, el traductor utilitza la variant aragonesa Guillén, més semblant al català, per comptes de Guillermo. El musical homònim de Dagoll Dagom va ser traduït a l'alemany per Harmut H. Forche el 16. III.2007, el qual conserva fidelment l'onomàstica original catalana.

Maria Rosa, traduïda al castellà per José Echegaray, va ser estrenada a Madrid el 24. XI.1894 (Martori 1995: 57). Els noms són castellanitzats o substituïts per d'altres completament diferents: la forma castellana de Marçal és Marcial, el qual sona potser massa guerrer i no és tan sonor com en català, per la qual cosa va ser substituït per Ramón mentre Quirze i Calau (deformació fonètica de l'hipocorístic de Ni-colau) i Badori (hipocorístic de Salvador) han estat fidelment traduïts pel seus equivalents castellans: Quirico, Colás i Salvador (sense hipocorístic); per al motius connotats Xic (Petit) i Gepa (Geperut) es recorre a Chicote i a Chepa; per a aquest darrer s'ha castellanitzat la fonètica perdent-se la connotació semàntica.

Mossèn Janot, traduït per Fernando Díaz de Mendoza i estrenat a Madrid el 18. III.1898, segueix molt fidelment els noms originals, sobretot els dels personatges principals (Martori 1995: 93) amb excepció del Mossèn Janot, que rep el seu tractament religiós adient castellà amb el corresponent diminutiu (Padre Juanico). Tots els altres personatges secundaris resten iguals que en català o són

35 Una de les primeres traduccions d'El Quijote a l'alemany del 1648 duia el títol: Don Kichotte de la Mantzscha, Das ist: Juncker Harnisch auss Fleckenland; en el pròleg el traductor justifica la denominació de «Juncker Harnisch» per ser un nom i tractament nobiliari més comprensible per al públic alemany mentre que «Fleckenland » és la traducció literal de La Mancha (Debus 2002: 96, n. 170).

36 Els principals traductors al castellà varen ser José Echegaray i Fernando Díaz de Mendoza, dos amics de Guimerà, per la qual cosa es podria deduir que la traducció de l'onomàstica devia ser amb l'aprovació o col·laboració del dramaturg. 
castellanitzats fonèticament o morfològica: Pasquala (Pascuala), Hilari (Hilario), Jordi (Jorge), Lluc (Lucas) i Llorençó (Llorensó),

Terra baixa, traduïda per Echegaray i estrenada el 27. XI.1896 a Madrid, abans de la versió catalana el 8. II.1897, conserva els noms originals catalans i només tradueix Josep (José) i Perruca (Peluca); en traduccions posteriors es castellanitza el nom del moliner Xeixa basant-se en el de l'òpera alemana Tiefland: Moruccio, que esdevindrá Morrucho (Martori 1995: 75). Les versions operístiques Tiefland i La catalane procuren apropar els noms d'acord amb les idees del públic respectiu sobre l'onomàstica de l'Europa meridional. El llibretista Rudolf Lothar emprarà a Tiefland sobretot noms italians: Sebastiano o Tommaso i el Mossèn esdevindrà el «Pfarrer» (rector). Més problemàtica és la traducció de Manelic, que, com hem vist ja abans, conté moltes connotacions; malgrat la italianització dels altres noms, el llibretista va decantar-se per un nom castellà, perdent-se el significat afectiu original i la individualització característica del protagonista: Pedro. Aquesta opció va causar més tard una col-lisió a l'hora de traduir el nom de Pere Màrtir de La filla del mar ${ }^{37}$. Louis Tiercelin i Paul Ferrier segueixen altres principis en el llibret de La catalane orientant-se sobretot cap a l'onomàstica castellana i apartant-se alhora dels noms primigenis, els quals tindrien també un equivalent francès: Anita (Marta), Don Miguel (Sebastià), Andrés (Manelic) i Agnès (Nuri); per a la resta dels pagesos recorre a noms castellans diferents del repartiment català: Blas, Gaspar i Mateo.

La filla del mar va ser estrenada primer a Buenos Aires el 12. IX.1899 i a Barcelona el 6. IV.1900. Echegaray tradueix fidelment els noms al castellà: Águeda, Catalina, Luisa, Gregorio i Cinquenas, mentre que Rufet i Baltasanet perdran llur diminutiu (Martori 1995: 119). No obstant això, el protagonista masculí principal passarà a anomenar-se Tomás Pedro per comptes de Pere Màrtir, el qual potser fonèticament sona millor en castellà i transmet més adequadament el caràcter fatxendós i doner del personatge; per altra banda, conserva el motiu primigeni de Mòllera (peix) sense recórrer a l'equivalent caste1là Barbada. Ferdinando Fontana a l'òpera italiana La nereide manté l'onomàstica catalana, italianitzant i simplificant només Pere Màrtir en Pietro i Gregori en Gregorio. A la versió alemanya Liebesketten, situada a la Bretanya, Rudolf Lothar introduirà un antropònim francès (Noel) per a un taverner, un protagonista nou, segurament a fi de conferir així un cert colorit nominal local. A diferència de Tiefland, Lothar a Liebesketten divergeix de l'onomàstica italiana o castellana cercant més noms exòtics i insòlits per als personatges principals: Sadika i Peter Martin, mentre que Mariona i Baltasanet es germanitzaran amb Marion i Balthasar. Com ja s'ha esmentat abans, a Tiefland ja havia anomenat Pedro el protagonista principal, per la qual cosa recorre aquí a

37 En algunes cartes a Artur Vinardell (Guimerà 1978: 1485, 1487), confirma el seu desig que les traduccions de les seves obres siguin fidels i literals. No obstant això, malgrat els canvis onomàstics i argumentals sembla que estava molt satisfet amb el llibret de Tiefland (Raupp 1930: 180), tot i que en una carta a d'Albert del 1908 va comunicar-li que no trobava cap semblança amb l'original (Raupp 1930: 222). 
la traducció alemanya de l'original català amb un complement fonèticament semblant: Peter Martin.

\section{CONCLUSIONS}

3.1 Guimerà no acostuma a repetir gaire els aproximadament 600 antropònims, alguns dels quals titularan alguns drames. Sobretot a les obres del s. XIX mostra una tendència a recórrer a noms catalans, sia corrents, sia rebuscats. A les peces del s. XX, pel contrari, d'acord amb la internacionalitat de les trames argumentals batejarà els personatges amb noms forasters i reflectint la realitat social de Catalunya també amb noms castellans o amb interferències castellanes, sobretot fonètiques. Al repartiment no són mai esmentats ni els personatges absents ni els pseudònims. A través del nom personalitza molts animals, els quals és obvi que no apareixen en escena, tot i que en alguns casos preveu a les acotacions que hi actuïn. Altres tipus onomàstics són els teònims, els quals reflecteixen les divinitats corresponents a la religió dels protagonistes i també caracteritzarà amb noms els transports públics i les campanes.

3.2 Quant a la tipologia, poden classificar-se en noms parlants, els quals ja d'antuvi, per la semàntica o morfologia, comuniquen un significat determinat $i$, especialment, els motius connotats, que expressen clarament l'ofici o origen de l'anomenat. En anonimitzar un personatge, sobretot si incorpora un paper principal, se li denega d'entrada el seu dret d'una personalitat pròpia. Els diminutius i augmentatius coadjuvaran a denotar el grau d'afecte o rebuig, proximitat o distància entre els protagonistes. Un nom sonor confereix, ja pel seu mer to, una predisposició simpàtica envers la persona que el duu, així també com els classificadors i personificants, els quals estableixen una associació basada en criteris religiosos, nacionals, socials, geogràfics o literaris. Mitjançant els comentaris d'altres protagonistes Guimerà revela la seva postura favorable o negativa davant d'alguns noms determinats.

3.3 Molts antropònims caracteritzen ja d'antuvi la funció dels personatges, sia denotant llur condició social (noms vulgars o sofisticats) o el paper que representaran (Isabel connota d'antuvi la Jezabel bíblica, és a dir una dona fatal; Blanca, bondat i innocència). També poden influir en el desenvolupament de la trama, desvetllant associacions afectives simbòliques, per exemple el Saïd reaccionarà sentimentalment davant el nom de Blanca, el qual li recorda la seva mare difunta. Un cas especial és el de Manelic, el qual, malgrat el diminutiu, individualitza un heroi de gran talla.

3.4 Caldria que la traducció de l'onomàstica teatral s'adaptés als coneixements i cultura del públic receptor, transmetent les possibles denotacions i connotacions semàntiques i etimològiques del text de partida a fi de caracteritzar millor els personatges dins la trama argumental. Exemples de traduccions fallides són les de Manelic (Pedro, Andrés) o Pere Màrtir (Tomás Pedro, Peter Martin, Pietro), en les quals l'aurèola, que irradia d'aquests noms en el text inicial, es perd completament en el text final. 


\section{BIBLIOGRAFIA}

Amades, J. (1979) Folklore de Catalunya, 2, Barcelona, Selecta.

Birus, H. (1987) «Vorschlag zu einer Typologie literarischer Namen», Zeitschrift fir Literaturwissenschaft und Linguistik, 17, 67, pp. 38-51.

Carlson, M. (1983) «The Semiotic of Character Names», Semiotica, 44, pp. 283-296.

Caravaca, F. (1933) Ángel Guimerá. Poeta de Cataluña, Barcelona, Maucci.

Debus, F. (2002) Namen im literarischen Werken. (Er-)Findung - Form - Funktion, Stuttgart, Steiner.

Goldoni, C. (1923) Mein Leben und mein Theater, Viena, Rikola.

Guimerà, À. (1975) Obres completes, I, Barcelona, Selecta.

- (1978) Obres completes, II, Barcelona, Selecta.

- (s.d.) Euda d'Uriach, doc. mecanografiat [signatura 83.115, de la Biblioteca de l'Institut del Teatre de Barcelona].

Maguire, L. (2007) Shakespeare's Names, New York, OUP.

Martori, J. (1995) La projecció d’Àngel Guimerà a Madrid (1891-1924), Barcelona, Curial.

Miracle, J. (1958) Guimerà, Barcelona, Aedos.

Nord, C. (1993) Einführung in das funktionale Übersetzen. Am Beispiel von Titeln und Überschriften, Tübingen, Francke.

Raupp, W. (1930) Eugen d'Albert, Leipzig, Koehler\&Amelung.

Rusiñol, S. (1973) Obres completes, 1, Barcelona, Selecta.

Soler, M. (2012) «La influència de Somni d'una nit d'estiu de William Shakespeare a La santa espina d'Àngel Guimerà», Journal of Catalan Studies, pp. 29-51.

Soler, M. (2014) «Jo no vull ser fill: components comicogrotescs a La santa espina de Àngel Guimerà», Episkenion, pp. 105-121.

Störig, H.-J. (ed.) (1973) «Einleitung», Das Problem des Übersetzens, Darmstadt, Wiss. Buchges., pp. VII-XXXIII (Wege der Forschung, 8).

Vilanova, E. (1949) Obres completes, Barcelona, Selecta. 


\section{APÈNDIX}

$\mathrm{AB}=$ Alta banca $; \mathrm{AC}=$ Aigua que corre $; \mathrm{AE}=$ L'ànima és meva; $\mathrm{AM}=$ L'ànima morta; $\mathrm{AN}=$ Andrònica; $\mathrm{AT}=$ Arran de terra; $\mathrm{BA}=\mathrm{La}$ Baldirona; $\mathrm{BJ}=$ La boja; $\mathrm{CN}=\mathrm{Al}$ cor de la nit; $\mathrm{CS}=\mathrm{El}$ camí del sol; $\mathrm{DD}=$ Per dret diví; $\mathrm{EL}=$ L'Eloi; EU = Euda d'Uriac; FA = La farsa; FB = La festa del blat; FM = La filla del mar; FR = El fill del rei; GC = El gos de casa; GP = Gala Placídia; IM = Índibil i Mandoni; JD = Joan Dalla; JN = Jesús de Nazaret; JT = Jesús que torna; JU = Mort d'en Jaume d'Urgell; JW = Judith de Welp; LA = L'aranya; MC = Mar i cel; MI = La Miralta; MJ = Mossèn Janot; MO = Mestre Oleguer; MR = Maria Rosa; MS = Les monges de Sant Aimant; NJ = El nen jueu; PB = En Pep Botella; $\mathrm{PE}=$ La pecadora; $\mathrm{PO}=$ En Pòlvora; $\mathrm{RJ}=$ La reina jove; $\mathrm{RL}=$ Rosa de Lima; RM = Rei i monjo; RV = La reina vella; $\mathrm{SE}=$ La santa espina; $\mathrm{SP}=$ La sala d'espera; $\mathrm{SS}=$ Sol, solet...; ST = Sainet trist; TB = Terra baixa; TI $=$ Titaina.

\begin{tabular}{|c|c|c|}
\hline Abdalla (MS) & Almahí (CS) & Armanyac, Senyor d' (RJ) \\
\hline Abrial, Gran Duc d' (DD) & Amèlia (AC) & Armengol (CS) \\
\hline Adelart (JW) & Amon, Sor (MS) & Armida, Comte d' (DD) \\
\hline Agar (CS) & Andreu (PE) & Arnolt (SE) \\
\hline Àgata (FM) & Andrònica (AD) & Arraut (CS) \\
\hline Agna (PE) & Anton (EL) & Asgort (IM) \\
\hline Agnès (RM) & Anton (MI) & Astor ((AM) \\
\hline Agneta (BA) & Anton (SP) & Atarès (RM) \\
\hline Albert, Germà (BJ) & Anton (TI) & Ataülf (GP) \\
\hline Albert, Mr. (PE) & Anton Cadernera (LA) & Aymerich (FR) \\
\hline Albertó (CN) & Antònia (AC) & Aymerich, Cavaller d' (RJ) \\
\hline Albeses, Duc de les (RV) & Antònia (BA) & Baàlia (IM) \\
\hline Àlbia (DD) & Antònia (PE) & Babarotes (SE) \\
\hline Aldena, Sor (MS) & Antònia (TB) & Bacahit (CS) \\
\hline Alderic (AE) & Antonieta (AT) & Badori (MR) \\
\hline Aldret (RJ) & Antonieta, Sra. (AB) & Baldirona (BA) \\
\hline Aleix (FB) & Apagallums (SE) & Baldomero (AB) \\
\hline Alèxia, Reina (RJ) & Arban (IM) & Baltasanet (FM) \\
\hline Alexis (AN) & Arding, Baró d' (JT) & Baltasar, Don (FA) \\
\hline Alexis (JT) & Argonat (CN) & Beatriu, Dona (RV) \\
\hline Alí Paixà (AE) & Arlet, Vescomte d' (JT) & $\mathrm{Bel}, \mathrm{La}(\mathrm{CN})$ \\
\hline
\end{tabular}




\begin{tabular}{|c|c|c|}
\hline Beneta (EL) & Carlot (JT) & Didier (FR) \\
\hline Berenguera (MS) & Carmeta (EL) & Dimas (FB) \\
\hline Bergadà, Senyor & Catarina (FM) & Domingo (FA) \\
\hline \multirow{2}{*}{$\begin{array}{l}\text { Bergamote, Baronessa } \\
\text { de (RJ) }\end{array}$} & Cebrià (DD) & Dora (DD) \\
\hline & Cebrià (MS) & Dorman $(\mathrm{JT})$ \\
\hline Bernabé (SS) & Cecília (AC) & Duran (JD) \\
\hline Bernadot (FR) & Cèlius (GP) & Egla (AM) \\
\hline Bernard (JW) & Cercapous (SE) & Eguinart (FR) \\
\hline Bernat (MS) & Cigonya (SE) & Elda (DD) \\
\hline Bernat (RV) & Cinquenes (FM) & Elena, Sor (AN) \\
\hline Bertrand (AM) & Ciriac (AE) & Eloi (BA) \\
\hline Blai (AR) & Ciriac (SE) & Eloi (EL) \\
\hline Blai (JD) & Cisa (RV) & Eloi (PO) \\
\hline Blanca (MC) & Climenta (MJ) & Enric (BJ) \\
\hline Blanca, Reina (RV) & Colmar $(\mathrm{CN})$ & Enric (MI) \\
\hline Blanqueta (AE) & Coritza (IM) & Enric, Rei $(\mathrm{CN})$ \\
\hline Blasi (BJ) & Cornel (RM) & Ervic, Fra (AM) \\
\hline Bonet, Sr. (AB) & Cosme (BA) & Escleri (CS) \\
\hline Brandi (CN) & Cosme Arnabó, Don (FA) & Esperanceta, Donya (SP) \\
\hline Brandi (AE) & Cristina (EL) & Esquirol (FA) \\
\hline Brauli (DD) & Cusefa (ST) & Estanislau (AC) \\
\hline Broida (IM) & Dagobert (AM) & Esteve, Gran Duc (RJ) \\
\hline Brunegilda (JW) & Dalmau (CS) & Euda (MS) \\
\hline Brunsberdec, Duc de (RJ) & Damià (BJ) & Eudald (TI) \\
\hline Cabirol (DD) & Daniel (FA) & Faci (FB) \\
\hline Calau (MR) & Daniela (PE) & Feliça (ST) \\
\hline Candiona (FA) & Demetri (AN) & Felícia (AT) \\
\hline Candro (ST) & Demetri (CS) & Felipa (AR) \\
\hline Carles (JW) & Demetri, Príncep (JT) & Felipa (MJ) \\
\hline Carles (MC) & Deri (FA) & Felipó (MS) \\
\hline Carles (MI) & Desirac (DD) & Ferran (AM) \\
\hline Carlot (DD) & Dèvora (MI) & Ferran (MC) \\
\hline
\end{tabular}


Ficatatxes (SE)

Figueres, Hereu (SS)

Filibert (RJ)

Filomena (FM)

Filomena (RV)

Fondaina, Duquesa (RJ)

Francesc (JD)

Francesc (PO)

Francisca (AC)

Francisqueta (AR)

Frits (RJ)

Fruitós (FA)

Gabriel, Don (AB)

Gaetana (SS)

Gal-la Placídia (GP)

Galín (RM)

Gaspar (MS)

Gasparona (AR)

Gelassi (AN)

Genaro, Don (AB)

Georgeta $(\mathrm{CN})$

Gepa (MR)

Gerda (IM)

Geric (JW)

Gervasi (JD)

Gerves, Senyor de (DD)

Gila (SP)

Gilot (CN)

Ginart (DD)

Gircon (CS)

Gisembert (JW)

Gladys (JT)
Godmir (SE)

Gontran (FR)

Gori (PO)

Gran (SS)

Gregori (FM)

Gregori, Don (MI)

Grèvola (IM)

Grill, Vescomte de (RJ)

Gringní, Baró de (JT)

Gringoire, Madame de (JT)

Griselda, Comte de (RV)

Gualbes (AM)

Gualter (DD)

Guerau (AM)

Guerau d'Arenes (CS)

Gueridó (SE)

Guillem (AM)

Guillem (FR)

Guillem (MC)

Guillem (MS)

Guillem (RJ)

Guisla, Fra (RM)

Guixots (SP)

Hassèn (MC)

Heràclias (AN)

Hierbas, Senyor (BA)

Hilari (MJ)

Hildebrand, rei (DD)

Hipòlit (SS)

Hipòlit (RL)

Hirak (CS)
Huguette (PE)

Ibis, Marquesa d' (RJ)

Indíbil (IM)

Isaac (AN)

Isabel (AR)

Isabel, Donya (AB)

Ismael (MS)

Jan Talèia (RJ)

Jana (ST)

Janot, Mossèn (MJ)

Jan-Toni (CN)

Jaume (AE)

Jaume (FB)

Jeanne (PE)

Jeroni (AT)

Joan (AE)

Joan (EL)

Joan (JT)

Joan (MS)

Joan (SP)

Joan Dalla (JD)

Joan de Nargó (CS)

Joan Lladons (PO)

Joan, Pare (AN)

Joana (BJ)

Joana (JT)

Joanet (MI)

Joanet (SS)

Joanetet (EL)

Joanot (MC)

Joaquim, Don (PE)

Jofre, Fra (RM) 


\begin{tabular}{|c|c|c|}
\hline Jon (SS) & Macià, Sr. (AB) & Martirià (AE) \\
\hline Jonell (DD) & Magdalena, Senyora & Mary (AE) \\
\hline Jordi (AN) & & Masela (CS) \\
\hline Jordi (MJ) & Mahalta, Sor (MS) & Mateu (AN) \\
\hline Jordi (SE) & Mahomet (MC) & Matias (MJ) \\
\hline Jordi, Mossèn (BJ) & Malek (MC) & Matias, Sr. (AB) \\
\hline Jòria (IM) & Malfuró (RJ) & $\operatorname{Max}(\mathrm{PE})$ \\
\hline Josep (AB) & Mandoni (IM) & Màxim (IM) \\
\hline Josep (JT) & Manel (BJ) & Menciona, Senyora (SP) \\
\hline Josep (TB) & Manela (FB) & Méndez (FA) \\
\hline Josep Comas (PB) & Manelet (FA) & Menéndez (FA) \\
\hline Josepet (EL) & Manelic (TB) & Meri (MI) \\
\hline Josepó (ST) & Mànlius (IM) & Migranell (DD) \\
\hline Juanito (AB) & Manuel (AC) & Mingo (BA) \\
\hline Judit (JW) & Marçal (CN) & Minguet (PO) \\
\hline Julià (JD) & Marçal (MR) & Miquelàs (ST) \\
\hline Kahel (CS) & Marcel (FR) & Miqueló (PE) \\
\hline Kalep (CS) & Marcel·lina (AC) & Miqueló (SP) \\
\hline Kir Miqueli (CS) & Màrcius (GP) & Miquelot (RV) \\
\hline Laia (JD) & Marcó (PO) & Miques (EL) \\
\hline Laia (SE) & Margalida, Dona (RV) & Mirga (IM) \\
\hline Laureano, Don (GC) & Maria (SE) & Mòllera (FM) \\
\hline Leocàdia (RL) & Maria Rosa (MR) & Mònica (AE) \\
\hline Lionel (FR) & Maria Rosa (NJ) & Mònica (RL) \\
\hline Lisana (RM) & Maria, Sor (AN) & Moniqueta (MI) \\
\hline Livani (AN) & Mariagna (RV) & Monsa (PE) \\
\hline Llargas (FA) & Mariagna (ST) & Montabrany (AM) \\
\hline Llèdia (GP) & Marieta, Donya (FA) & Morelli, Comendatore \\
\hline Lleonart $(\mathrm{CN})$ & Mariona (FM) & $(\mathrm{JT})$ \\
\hline Llorençó (MJ) & Marta (TB) & Mossèn (TB) \\
\hline Lluc (MJ) & Martí, Sr. (AB) & Munda (RL) \\
\hline Lluïseta (FM) & Martinet (FB) & Munda (SS) \\
\hline
\end{tabular}




\begin{tabular}{|c|c|c|}
\hline Munda (GC) & Pau Trits (SS) & Raimon (AE) \\
\hline Munda, Pia (AT) & Paula (MJ) & Ramir (RM) \\
\hline Mura, Comte de (RJ) & Pegadolça (SE) & Ramon (AC) \\
\hline Nadala, Donya (MI) & Pelegrina, Senyora (FA) & Ramon (AT) \\
\hline Nando (TB) & Pepa (AR) & Ramon (EL) \\
\hline Nataniel (JT) & Pepa (JT) & Ramon (PE) \\
\hline Nicèfor (AN) & Pepa (MI) & Ramon (PO) \\
\hline Niceta (ST) & Pepa (TB) & Ramon (SP) \\
\hline Niceta $(\mathrm{NJ})$ & Pep Botella (PB) & Ramon, Mossèn (BA) \\
\hline Niceta (GC) & Pepet (AT) & Rasés (JW) \\
\hline Nikelas (AN) & Pere l'Ermità (MS) & Remedios (FA) \\
\hline Niva, Sor (AE) & Pere Màrtir (FM) & Renat (MS) \\
\hline Nofre (BJ) & Peret (FA) & Restany (SE) \\
\hline Noi Sucre (AR) & Peret (MS) & Richard (PE) \\
\hline Norian $(\mathrm{CN})$ & Peretó (AR) & Ripollès (MI) \\
\hline Nuri (TB) & Perot (CS) & Rita (FA) \\
\hline Nyerris (TI) & Perruca (TB) & Rita, Sra. (AB) \\
\hline Ofíria (CS) & Petra, Senyora (BA) & Robert (FR) \\
\hline Oliver (JD) & Petronella (AM) & Robert. Sr. (AB) \\
\hline Oliveta (DD) & Pia Munda v. Munda, Pia & Robert, Sr. (AB) \\
\hline Oliveta (MS) & Plegamans (BA) & Roc (MC) \\
\hline Oliveta (ST) & Pona (PE) & Roderic (MS) \\
\hline Oriola $(\mathrm{FB})$ & Ponci (IM) & Rodolf, Rei (JT) \\
\hline Orís, Marquès d' (RJ) & Querol, Sr. (SS) & Roger (MS) \\
\hline Orlof, Comte d' (JT) & Quic (RL) & Roger de Flor (CS) \\
\hline Ornec (IM) & Quica (FB) & Roland (RJ) \\
\hline Osman (MC) & Quim (BJ) & Roldana (MS) \\
\hline Osvald (AM) & Quirze (DD) & Ròmul (IM) \\
\hline Pacomi (AN) & Quirze (MR) & Rosa (AT) \\
\hline Pa-i-ceba (SE) & Quirze (RV) & Rosa (SP) \\
\hline Palmar (DD) Fisteu (DD) & Rafel (AT) & Rosa de Lima (RL) \\
\hline Pasquala (MJ) & Rafel (SP) & Rosa Vera (SE) \\
\hline
\end{tabular}




\begin{tabular}{|c|c|c|}
\hline $\begin{array}{l}\text { Rosamaia, Comtessa de } \\
\text { (RJ) }\end{array}$ & Sigeric (GP) & Tomeu (MS) \\
\hline & Silvestre (MJ) & Tonet (ST) \\
\hline Rosària (BA) & Slavis (JT) & Toni (MJ) \\
\hline Rosària (EL) & Somiquet (MS) & Toni (PO) \\
\hline Rosella (DD) & Surba (IM) & Tornamira (RJ) \\
\hline Roseta (AC) & Talarn, Coronel (JT) & Torrexica, Comte de la (RJ) \\
\hline Rosó (MJ) & Tallanassos (SE) & Tramulles (SP) \\
\hline Rovellat, Capità (RV) & Taneta (PO) & Trianar, Duquessa del \\
\hline Rufet (FM) & Tano (AR) & \\
\hline Sadurní (MI) & Tastets (BA) & Trinitat, Mossèn (EL) \\
\hline Safar (CS) & Telm (FB) & Trumfos (SS) \\
\hline Saïd (MC) & Teòfil (AN) & Tura (EL) \\
\hline Salvador (AT) & Teranyines (SE) & Ulric (DD) \\
\hline Salvadora, Donya (FA) & Teresona (MJ) & Ulric (SE) \\
\hline Sàmit (CS) & Tèudia (FR) & Urilda (MS) \\
\hline $\begin{array}{l}\text { Sant Thimur, Abat de } \\
\text { (AN) }\end{array}$ & Tibalt (MS) & Urla (SE) \\
\hline Saut (IM) & Tirnova, Marquès de (RJ) & $\begin{array}{l}\text { Valentí (EL) } \\
\text { Valeri (PE) }\end{array}$ \\
\hline Sebastià (TB) & Tirnova, Marquesa (RJ) & Valterra (RM) \\
\hline Sebastià, Don (SP) & Tit (ST) & Varogast (GP) \\
\hline Sèbio (FB) & Titaina (TI) & Vèlia (GP) \\
\hline Secallona (SE) & Toast (RJ) & Vermon, Fra (JW) \\
\hline Segimona (RV) & Tomàs (AE) & Vernulf (GP) \\
\hline Seguret, Marquesa de & Tomàs (AT) & Vespa (SE) \\
\hline & Tomàs (MI) & Vicentó (FB) \\
\hline Selim (MS) & Tomàs (PV) & Vileta (PO) \\
\hline Sema (CS) & Tomàs (SP) & Vladimir, Gran Duc (RJ) \\
\hline Sergi (AN) & Tomàs (SS) & Xeixa (TB) \\
\hline Sergi $(\mathrm{JT})$ & Tomàs (TB) & Xeminells, Senyor de \\
\hline Serní (RV) & Tomàs (TI) & \\
\hline Servili (IM) & Tomasa (MR) & Xibecs (SP) \\
\hline Severet (JD) & Tomaseta (PE) & $\mathrm{Xic}(\mathrm{MR})$ \\
\hline Severí (MS) & Tomasot $(\mathrm{CN})$ & Ximena (RM) \\
\hline
\end{tabular}


